\title{
The Role of Regional Monitoring Assembly (MPD) Taking Control of The Check / Honorarium Services in The District of Cirebon
}

\section{Arif Rakhman ${ }^{1}$ and Jawade Hafidz ${ }^{2}$}

Abstract. Notary as a public official, as well as a profession, position is very important in helping to provide legal certainty for the public. Notaries must prevent legal problems later in life through authentic agreement he made as a perfect proof in court. Notaries have a role in activities run the legal profession that can not disconnect from the fundamental issues relating to the functions and roles of law where the law itself, which is defined as the legal rules that govern all public life. This authority can not be applied because it has not yet issued the implementing regulations for the expansion of the notary's authority. Keywords: Notary Official; The Function of Notaries; Notary Competition.

\section{Introduction}

Notary as public official, as well as a profession, position sting important in helping to provide legal certainty for the community. The notary must also prevent legal problems later in life through authentic agreement he made as perfect evidence in the court, a notary is a respectable profession is always attached to ethics and patronizing a notary ethics. Because the adherence to the notary profession ethics called noble profession (officium mobile). The authority of the notary, based on Article 15 of the law office of notary (UUJN) is made the authentic act of the agreements, agreements and statutes that are required by legislation and / or desired by the stakeholders to be stated in an authentic agreement guaranteeing the creation date of the agreement.

- As Office; UUJN a field unification of notary office setting means the only rule of law in the form of laws governing notary office in Indonesia, so that all matters related to the notary in the premises must refer to UUJN. Position notary is an institution created by the State or tasks that had been made by law for the purpose and function of the particular (specific authority) and are sustainable as a permanent work environment.

- Notaries Have A Certain Authority; Every authority given to the position should be no rule of law as the limit so that positions can work well and do not collide with other positions of authority.

- Appointed And At Stop By The Government

Article 2 UUJN determine that notaries are appointed and dismissed by the government in this case the minister in charge of notary (article 1 paragraph) ${ }^{3}$ Figures 14 UUJN Notary although administratively appointed and stoped by the government, does not mean that a notary be subordinated (subordinate) which taken by the government. Thus the notary in the line of duty ;

- Is independent (autonomous),

- Not favoring anyone (as impartial),

\footnotetext{
${ }^{1}$ Master of Notary's Student Sultan Agung Islamic University (UNISSULA) Semarang email rahmanarief94@yahoo.com

2 Lecture of Faculty of Law UNISSULA

${ }^{3}$ Habib Adjie 2008 Hukum Notaris di Indonesia Rafika Aditama Bandung p 15
} 
- Not dependent to Country whoever (independent) meaning of duty can not be interfered by the parties,

- Do not receive a salary or pension from the notary despite appointed and dismissed by the government but did not receive a salary, pension from the government. Notary only receive emoluments from people who have been on serve or to provide services free of charge to those who can not afford

- Accountability for work to people who need legal documents (agreement) is authentic in the field of civil law so that the notary has the responsibility to serve the public, the public can sue on civil notary and demanded indemnity costs and interest if such agreement may made not in accordance with the rules law it is a form of accountability to the public. ${ }^{4}$

Before you apply UUJN, supervision, inspection and sanctions against Notary done by a judicial body is on sanctions against notary performed by the judiciary that existed at that time, as has been set in article 140 of the Reglement op de rechtelijke organisatien en het der Justitie (Stbl, 187 no.23), buitengewesten Reglement article 96, section 3 Ordonatie Buitengerechtlijke verrichtingen - 1946 State institution number 135, and article 50 of the Notary supervision PJN then performed for the General and the Supreme Court as referred to in article 32 and 54 of Act No. 13 of 1965 on the Court in the General Courts and the Supreme Court and made circular glorious Council of Republic of Indonesia No. 2 of 1984 on procedures for Supervision of the Notary, together with Chairman of the Supreme Decree.

Since the presence of the institution notary in Indonesia Supervision of the notary is always carried out by the institute Justice and the government, that the purpose of the supervision order notaries when performing their duties of office meets all the requirements relating to the implementation of duties of office notary in order for the experience of the interests of society as a notary in the lift by the government not for self interest of notary itself but the people's interests are in services. Other objectives of the Supervision of Notaries, Notary at present that to serve the public interest ${ }^{5}$.

\section{Research Methods}

The research method that used is a normative legal research and library research studies evaluating a study of the documents, which uses secondary data such as legislation, court decisions, legal theory, and may include the opinions of the scholars.

\section{Discussion}

In Indonesia, the notary profession is quite old presence in Indonesia because Indonesia had been there since the $17^{\text {th }}$ century, or more precisely the date of August 27, 1620 whom Melchior Kerchen is the first served as a notary in Indonesia, after the appointment made by the Governor General Jan Pieterszoon Coen, the number of notary in the city related to the high growing need for services Public Notary notary and has since grown in all areas of Indonesia.

In the past Notary is an employee of an independent Oost so constrained not have freedom as now where the Notary is a independent of public official. Notary derived from the words "Notaries" the names given to the Roman people whose job running the work of the author at the time. There also are found Notary derived from the words "Literaria Memorandum" means the sign (letter marks or characters) that says.

\footnotetext{
${ }^{4}$ Ibid p 16

${ }^{5}$ Habib Adjie 2011 Majelis Pengawasan Notaris Rafika Aditama Bandung p 3
} 
Article 1 of Act No. 2 of 2014 About Notary, it defines as a public official authorized to make an authentic agreement and other authorities ${ }^{6}$.

Notary is a profession that requires a person having special expertise become professionals in the profession. As prosecutors, judges, and lawyers with the task and the competition to help people who have a legal problem. Therefore, in order to perform the profession then the position of public Notary as a respectable officer.

As a public authority granted by the State attributive through the Act to a person who believed, notary appointed by the Minister of Law and Human Rights.

Sjaifurrachman and Habib Adjie said that the notary is a public official whose sole authorized to make the authentic act on all agreements, agreements and determination required by a general regulation or by the interest desired to be stated in an authentic agreement purposes the certainty?

The Act no. 2 of 2014 On Notary has set clear tasks and authority of Notary. In Article 15 (1) states that the Notary authorized to make the authentic act on all agreements, agreements and regulations that may impose by regulation. Legislation and or that desired by the stakeholders to be stated in an authentic agreement guaranteeing date, agreement, saving agreement, giving grosee, copy, and official copies, all of it along a agreement it not also be assigned or excluded to other officials or any other person specified by the Act.

Before Running the Public Notary shall take an oath / pledge according to his belief in the presence of the minister or his representative. The Act No. 2 of 2014 concerning Notary;

Notary as a dedication to the community in terms of helping arrange permits a business entity solely as a form of legal services. Legal services provided Notary will get honorarium. Legal services Notary who received prize honorarium of society that is a agreement authentic grouped by UUJN or endorse / letters posted under the hand ${ }^{8}$ according UUJN and do the work in connection with the manufacture of an authentic agreement.

Here the problems start to appear, on the one hand as an extension of the government, granted that people who use services of a notary and wish to obtain services provided by the notary did not get the salary of the state in carrying out its obligations. receiving a request notary. The cost war in the profession of notary has been so severe that it is not uncommon in an effort to get clients, the notary tariff war', "Trading down" to the stage that can not make sense, as stated by the Asbar Imran who is a representative officer in Southeast of Celebes in the plenary meeting of the Central Executive notary associations of Indonesia which discusses widen the debriefing and refreshment of knowledge which was held on March 23, 2015 in Jakarta. Because of the low rates withdrawn from the client's common sense that the amount of fees, it seems impossible for the purposes of the production cost of the certificate produced. Although they know that in fact it is unethical, because it has violated the provisions set out in Article 4 point 10 code of conduct notary who states that: 4 "Setting the fee to be paid by the client in a lower amount of honorarium

\footnotetext{
${ }^{6}$ Suparman Marzuki Etika dan Kode Etik Notaris FH UII PRESS Yogyakarta 2017 p 62

${ }^{7}$ Sjaifurrachman and Habib Adjie 2011 Aspek Penanggung Jawaban Notaris Dalam Pembuatan Akta CV Mandar Maju Bandung p 100

8 http://pasca.unhas.ac.id/jurnal/files/8cf179cef3434887e9966350f597f5f0.pdf downloaded on Saturday 30th June 2018 at 16:37 pm

9 https://media.neliti.com/media/publications/116614-ID-honorarium-notaris-sebagai-upayauntuk-m.pdf downloaded on Saturday on Saturday 30th June 2018 at 16:50 pm
} 
predetermined association". The facts demonstrate that the provisions of the honorarium, well defined in UUJN and each regional board does not have the power, as argued by Habib Adjie also argues: "Inclusion of how the honorarium or fees in the Law on Notary does not have the nature of force to notary and the parties who require the services of a notary, merely as a reference or benchmark and no one is watching specifically related to honorarirum if there notary follow or not follow that provision ". So, in addition to not have the nature of force that needs to be underlined from Adjie statement is the sentence: "Nothing supervise if there notary follow or not follow these provisions" should be underlined. Whereas existing Regional Supervisory Council (MPD), which served to conduct surveillance. Apparently, the MPD have limitations in monitoring ".10

In this case the MPD has the authority under Article 15 regulations the Minister of Justice and Human Rights of the Republic of Indonesia Number M.20.PR.08.10 2004 governing the examination conducted to the Notary, namely:

- Regional Stewardship Council before making periodic checks in every time it deems necessary, to advance in writing to the Notary no later than seven (7) working days before the test,

- The notification letter as to paragraph (1) include the hour, day, date and name of the Regional Oversight Council members who will checking perform.

- At the appointed time for the inspection, notary concerned should be in his office and Notary Protocol.

MPD authority's regulations in Article 16, the Minister of Justice and Human Rights of the Republic of Indonesia Number 2004 M.02.PR.08.10 set the examination of the Public Notary Examination Conducted by a team that is; ${ }^{11}$

- Periodic examination carried out by the inspection team consisting of three (3) members of each of the elements formed by the Assembly Local assisted by 1 (one) secretary

- Inspection team referred to in paragraph (1) shall refuse to examine notaries who have marital relations or blood relative in a straight line up or down without restrictions degrees and a straight line till the third-degree laterally by a notary

- In terms of Inspection Team has a relationship referred to in paragraph (2), Chairman of the Regional Supervisor pointed the subtitussion.

Examining Team which examination results mentioned above shall be made Minutes and reported to the MPW, Official Notary office organization and MPW, it based on article 17 of Minister of Law and Human Rights of the Republic of Indonesia Number M.02.PR.08.10 of 2004, ie:

- Examination results Examination Team as referred to in Article 15 contained in the investigation report signed by the chairman of the Inspection Team and Checking of Notary

- The Minutes of examination referred to in paragraph (1) shall be submitted to the local Regional Control Panel with a copy to the concerned on Notary, the Notary bond Local administrators of Indonesia, and Central Supervisory Council

MPD authority is also set in the decision of the Minister of Law and Human Rights ${ }^{12}$ The Republic of Indonesia No. M. 39-PW.07.10 2004 as mentioned in item 1 point 2 of

10 https://media.neliti.com/media/publications/116614-ID-honorarium-notaris-sebagai-upayauntuk-m.pdf downloaded on Saturday on Saturday 30th June 2018 at 16:50 pm

${ }^{11}$ Habib Adjie 2017 Memahami Majelis Pengawasan Notaris (MPN) dan Majelis Kehormatan Notaris (MKN) Rafika Aditama Bandung p 16 
the Notary Supervisory Council task of carrying out the Authority as referred to in the PSAL 70,71 UUJN, article 12 paragraph (2), Article 14,15,16 and 17 laws and regulations of the Minister of Human Rights of the Republic of Indonesia Number M.02.PR.08.10 2004, and other authorities, namely:

- Delivering to Supervisory Council-Regional Council-Regional Supervising response regarding the objection against the decision of refusal for leave;

- Notify the Regional Supervisory Council of the alleged criminal element found by the Regional Inspector assembly on reports submitted to the Supervisory Council of Trustees region

- Noting permission granted leave in the leave certificate

- Sign and provide initial Register of Agreements and Special books which used to certify signatures under the letter of the hand and to record the letter under the hand

- Receive and administer the minutes of the handover protocol

- Convey to the Regional Supervisory Council:

- Periodic reports every 6 months or in July and January

- Every incidental reports in 15 days after granting leave

Regarding the authority of the Assembly Regional Supervising there is one authority of the Assembly of Trustees need to straighten rule of law in force, namely on the report the Assembly inspection if it finds an offense to conduct an examination of the Notary, the Council of Supervisors will report to Country authorities (article 32 paragraph (1) and (2) of the Regulation of the Minister) the substance of this article has put the Notary Supervisory Council as Reporting criminal offenses

According to Article 1 on 24 Book of Criminal Law (Criminal Code) that the report is submitted by a notification because based on Rights and Responsibilities Act to the competent authority on or moderate or expected occurrence of criminal events. Based on the contents of the article is eligible to become a reporting;

- A person;

- There based on Rights of Act obligations.

Supervisory Council is a body (article 1, paragraph (1) regulation of the Minister of Justice and Human Rights of the Republic of Indonesia No. M.02.PR.08.10 2004), with parameters such as this is associated with the Article 1 paragraph 24 (Criminal Procedure Code), that can be the complainant was the subject of law in the form of people, not the Assembly or related entities. ${ }^{13}$

\section{Closing}

\subsection{Conclusion}

- In this case there are some things that are done by notaries because of their desire or willingness urged him to do so because the notary must look at some of the conditions that office conditions where in the office there are employees who must be given a salary or wages for work in the office of the notary more and more employees will perform such activities or lowering tariff services (honorarium).

- In this case the notary just want to do / perform his profession as a Public Notary in general with the oath that had spoken before him at Inaugurated he had promised to meet the rules that apply in the provisions in UUJN or Law of Notary.

12 Habib Adjie Memahami Majelis Pengawasan Notaris (MPN) dan Majelis Kehormatan Notaris (MKN) ... op.cit. p 17

${ }^{13}$ Ibid $\mathrm{p} 18$ 


\subsection{Suggestion}

- Advice from me in order to be able to apply the notary honorarium tariff that has been set in order to compete in a healthy manner and also maintain the credibility of a Public Notary to be more awake again and there is no price competition or unfair tariff between notaries in Indonesia.

- In this case the Assembly Regional Supervisor must supervise notary faithful especially in the practice of tariff or honorarium that a notary be better in the future.

\section{References}

[1] Act No. 2 of 2014 on the Amendment of Act No. 30 of 2004 concerning on Notary

[2] Article 1 of Law No. 2 of 2014

[3] Habib Adjie 2008 Hukum Notaris di Indonesia Rafika Aditama Bandung.

[4] Habib Adjie 2011 Majelis Pengawasan Notaris Rafika Aditama Bandung.

[5] Habib Adjie 2017 Memahami Majelis Pengawasan Notaris (MPN) dan Majelis Kehormatan Notaris (MKN) Rafika Aditama Bandung

[6] Sjaifurrachman and Habib Adjie 2011 Aspek Penanggung Jawaban Notaris Dalam Pembuatan Akta CV Mandar Maju Bandung.

[7] Suparman Marzuki 2017 Etika dan Kode Etik Notaris FH UII PRESS Yogyakarta

[8] http://pasca.unhas.ac.id/jurnal/files/8cf179cef3434887e9966350f597f5f0.pdf

[9] https://media.neliti.com/media/publications/116614-ID-honorarium-notarissebagai-upaya-untuk-m.pdf

[10] https://media.neliti.com/media/publications/116614-ID-honorarium-notarissebagai-upaya-untuk-m.pdf 